\title{
Application of the Communicative Language Teaching in College Oral English Class
}

\author{
Xiujuan Li \\ Wuchang Shouyi University, Wuhan, 430064, China; \\ Xiangjun ,Xu \\ Wuhan Mechanical College, Wuhan, 430075, China
}

\begin{abstract}
To improve students' listening and speaking ability and cultivate thinking habit of speaking is the focus of English teaching. And CLT is the best choice to solve this problem. CLT focus on improving students' communicative competence through creating harmonious teaching environment, establishing fruitful teacher-student relationship and organizing effective classroom activities. Through the experiment done in the an independent college oral English class, this thesis tries to prove CLT is effective for improving independent college students' communicative competence by tests, questionnaire and interview to seventy non-English freshmen of our college by means of qualitative and quantitative methods. Besides, this thesis provides the teaching model of CLT. Through the painstaking organization of classroom teaching, students can experience the real communicative environment and can cultivate the ability of using language.
\end{abstract}

Key words- communicative language teaching communicative competence oral teaching

\section{INTRODUCTION}

Canale \& Swain said in their Theoretical bases of communicative approaches to second language teaching and testing that CLT refers to a set of communicative language teaching theories which are useful to communicative activities. (1980)

\author{
Zhongmin, Liu \\ Wuhan Mechanical College, Wuhan, 430075, China \\ Yu Mei \\ Wuhan Mechanical College, Wuhan, 430075, China
}

Richards\& Rodgers gave the following elements of learning theory. The communication principle is the first: Practice with real communication topics can improve learning. The second is the task principle: activities used in language for implementing meaningful tasks promote learning. The third is the meaningful principle: meaningful language to the learner is helpful to the learning process. Therefore, learning activities are chosen according to how well they involve the learner in meaningful and authentic language use.

There are the two quite different classifications for the nature of communicative language teaching: a "weak" version and a "strong" version of the approach. The former could be considered as "learning to use" the target language, the latter means "using (the target language) to learn it". The weak version claims that communicative teaching materials should supply the learner with opportunities to acquire communicative competence necessary and sufficient to be used in practical communication. On the other hand, the strong version of the CLT refers to the planning and implementation of realistic communicative activities, giving the learner an opportunity to acquire the target language itself during using it. If the teacher has the real interest in the needs and activities of the students, and if the students can talk to another and express and share their thoughts and feelings, practical communication can become true.

Both the language teaching methods abroad and the social needs in china influence language teaching 
methods which are used in English classroom.

CLT is best for China from the following reasons. First, the use of CLT has the supporting of Chinese government. The Chinese government thinks that the application of CLT will have many advantages to China. By applying CLT, teachers can keep up with developments in English teaching methods in the international world. In contrast, teachers will be confined into the traditional way of teaching, where the process of language teaching is reduced to the only analyzing of grammar and vocabulary. In addition, applying CLT will be helpful for learners to develop higher ability for communication. They will no longer be "unable to communicate properly". Second, difficulties are not permanent. Although there are difficulties and obstacles in the process of application of CLT, teachers can overcome them if they have a clear understanding of problems and try their best to adapt themselves to the training of CLT. And there are supports and improvement from some aspects of society. For example, the textbook contents have been changed partly to include more oral practice activities. Large classes have been reduced in some colleges to promote the application of CLT. And the government has poured more funds into training the teachers.

The most important thing for us to do is to clearly know the current teaching situation in china and to understand correctly the principles of CLT and the true meaning of "being communicative".

\section{Methodology}

The subjects consist of 70 students who are freshmen from 2 parallel classes of 2014 (respectively from Electronics and Law Department) in Wuchang Shouyi University. There were 35 students in each class and they were divided into two groups, the experimental group and the control one. Both classes were taught by the same teacher. In the experimental class, the teacher applied CLT while in the control one the traditional teaching method was taken.
A questionnaire was administered in the two classes at the beginning of the experiment with the purpose to know thoroughly the conditions of students' oral English learning. Questions included theirs difficulties in oral English learning, their needs to improve their oral English communicative competence, and the time they spent on oral English practice every day, and so on. After the questionnaires were completed and collected, the data were keyboarded into the computer for further analysis.

The researcher planed an interview to three students from the experimental class in a group to know their attitudes towards CLT and oral English learning and their achievements at the end of the experiment

\section{Results and discussion}

There are 21 and 19 male students respectively in the control class and experimental class which are $57.1 \%$ of all subjects. And $42.9 \%$ of subjects are female students ( 14 females are in the control class and 16 females are in the experimental class). The percentage of gender in the two classes is generally equal. So, there is no gender factor to influence the validity of experiment.

$10(14.3 \%)$ students thought that the level of their oral competence was very low ( 5 in the control class and 5 in the experimental class). 21(30\%) students regarded the level of their oral competence as low (11 in the control class and 10 in the experimental class). 23(32.9\%)students said that the level of their oral competence was average(10 in the control class and 13in the experimental class). And $13(18.6 \%)$ students thought that the level of their oral competence was fairly satisfactory (7 in the control class and 6 in the experimental class). Only 3(4.2\%) students thought that the level of their oral competence was satisfactory.

Students who are from Hubei province have the better basis in listening and speaking than those who are from northern China including Shandong, Hebei and Henan provinces. And students from Guangdong province have the highest level of oral competence and the highest 
motivation to take part in class activities. According to $\mathrm{Xu}$ (2000), individual characteristics should be taken into consideration. The teacher should understand students' different background and different needs in learning oral English and then can assign classroom activities with the proper level. Only comprehensible input can facilitate learners' learning in target language. Materials and topics should be chosen by the level of students. During the process of experiment, the researchers pay more attention to these provincial features of students, trying to avoid dividing students who are from northern China into one group.

We find students in experimental class have considerable difficulties in learning oral English. In the first and second statement, more than $77 \%$ subjects consider their biggest problem in learning oral English is how to express themselves confidently. And even $91 \%$ subjects have no courage to speak in class. That is to say, they have not enough speaking skills practice and the teacher doesn't encourage them to open their mouths in class. So they give up the chance to practice communicative competence in communication and just wait and see. But they have intense desire to speak fluent oral English. CLT advocates the teacher in the classroom should be the helper and facilitator for students. The teacher should encourage students through organizing proper activities for students to participate in.

The statement 3 is about time spending on oral English practice after class. $68 \%$ subjects scarcely practice oral English, and only $22 \%$ subjects can positively use English to communicate with others. For practicing oral English, the environment outside of the classroom is also important for them.

CLT is a kind of student-centered teaching method. Students are the center of classroom activities. Statements 4 and 5 indicate that all the classroom activities can not encourage students to really participate in them. And students have been familiar with the traditional teaching method. Because the English class is teacher-centered, classroom activities are just teacher's talking, questioning and supplying exercises. Students will feel bored and uneasy; gradually they lose their interest in learning English. Affected by the traditional teaching method, the teachers may be used to rely on the textbook and the teaching plan without applying CLT. The teachers lack the strategies and confidence in organizing the group work in class. So the effectiveness of CLT can not be performed perfectly. And sometimes the CLT class can not organized with high quality. Even sometimes it is wasting time because the activities can not function in improving students' oral ability. To deal with it, the teachers' training on knowledge of CLT and skills on how to use it should be taken into consideration. For themselves, the teacher should recognize the change of his role in CLT class that is the organizer, helper, instructor and participator not the authority. And the teacher should try to create democratic and challenging environment in class.

In statement 6 and 7, we also can find the problem in teaching method. That is, teachers never emphasize the communication in English, and they can not encourage students to speak in English and hardly give students time to communicate in class.

Besides teaching method, the textbook and materials used in English class are also worth considering. The level of textbooks should be suitable and the contents of it should be interesting and instructive. 86\% subjects think the materials now used can not arouse their interesting in communication. There are students with different level in one class. They have different needs on textbook. Some top students would feel boring and useless for them to do the tasks assigned on the requirements of the text; while some students who have difficulties in learning English will feel puzzled when the textbook is left aside. They don't know what to do and how to get information they need. It is necessary to use the textbook in oral class, but how to choose proper textbook and materials to meet different students' needs become a big problem. Besides the textbook, audio and video materials should be chosen properly too. There are so many kinds of materials which may not meet college students' needs. It is not only the teacher's duty but also the society to offer proper materials and textbooks to students. 
From the analysis and discussion above, we can come to a conclusion that students have some difficulties in oral English: lack of confidence, lack of enough time and proper instructions. They need the real useful and encouraging atmosphere to practice their oral English. Teachers should change their attitudes towards English teaching, and they also need change their teaching method--------the CLT is the most effective method to cultivate the students. Only through the change of attitudes and beliefs of the teacher and students together can oral class have a real and positive effect on students' oral competence. And the teacher should have the duty to help students change the habits of learning English from only depending on teachers' explanation in class to actively taking part in class activities to make sure that students are the center of CLT oral class. The teacher can be the helper, facilitator of the students in CLT class not the controller of it.

This section reports the results of Pre-test and Post-test implemented before and after the experiment. To perform new teaching method among students, one important point must be taken into account to check whether there were no statistically significant differences in average proficiency between the experimental class and the control class.

We can see the mean score of the pre-test in the experimental class and the controlled class is 77.54 and 77.62 respectively. The mean score of experimental class is 77.54 marks slightly lower than that of the control class, which means the oral English competence from the two classes are at the same level. In table 8, the results show that the t-score of independent sample between the experimental class and the controlled class is 0.063 , and the significant result of 2-tailed is $0.950(\mathrm{p}>0.05)$. So we can conclude that the experimental class and the controlled class obtain similar mean and standard deviation in their English knowledge background, which showed there is no significant difference in the pre-test between two classes before the experiment.

Students' performance in six aspects is not balanced. In the experimental and control class, there is the same problem in the speech rate and semantic expression with low mean score that is $13 / 13$ and 11/12. Students have the higher scores in grammar and linguistic structure. Pronunciation and intonation were in the middle level. Fluency is more important than accuracy in the process of communication. The successful communication should refer to the actual exchange and receiving of language. So, the teacher should pay more attention to students' communicative performance during the teaching, giving more time and chances to practice in fluent language. And we also can find that there is no big difference between the experimental class and controlled class in these six aspects.

However, the mean score of the post-test in the experimental class and the control class is 85.60 and 80.94 respectively, and the difference is statistically significant. The mean score of the experimental class is 85.60 marks much higher than that of the controlled class (which is 80.9429) after the experimental. In table 11, the results show the t-score of the independent sample between the two classes is 3.580, and the significant result of 2-tailed is $0.001(0.001<0.05)$. That is, the oral English competence of the experimental class has been improved greatly than that of the control class after CLT is adopted.

Compared with the control class, the big progress of fluency of students in the experimental class proved that CLT is more effective on improving students' oral competence than the traditional teaching method. It can be found the mean scores of the two classes have been improved after the experiment, especially that of the experimental class, which is much higher than that of the controlled class. All the statistics indicate that CLT is better than the traditional method in improving students' oral competence.

\section{Conclusion}

In this thesis, the author can draw some conclusions through analyzing the data from the pre-test and post-test and the results of the questionnaire and interview.

According to the results of pre-test and post-test, the 
scores of students in the experimental class and the control class are all improved in different degrees. But from the comparison between the mean scores of the two classes, we find that students in experimental class made much more progress in their oral competence, while the students in control group, who were taught by the traditional teaching method, made a little progress, which prove that the CLT is effective to improve students' oral competence.

According to the interview, most students enjoy the cooperative and competitive environment in CLT classroom which encourage them willing to take part in the activities to practice oral competence.

In a word, CLT is effective in the following aspects: 1) it creates a useful classroom atmosphere to facilitate students' participation in the oral practice activities. 2) it focuses on giving students more time to practice in the classroom which ensure that students are the center of the classroom. 3) it creats a kind of fruitful relationship between the teacher and students which can help the performance in class. 4) it had been proved to be an effective way to improve students' oral competence.

\section{References}

[1] Andrew, D. Cohen. Strategies in Learning and Using a Second Language [M]. Foreign Language Teaching and Research Press. 2000.

[2] Canale, M. \& Swain, M. Theoretical bases of communicative approaches to second language teaching and testing [J]. Applied Linguistics, 1980, $1: 1-47$

[3] Ellis, R. The Study of Second Language Acquisition [M]. Oxford: Oxford University Press. 1994.

[4] Richards, J. \& Rodgers, T. Approaches and Method in Language Teaching: A Description and Analysis [M]. Cambridge: Cambridge University Press.1983

[5] Xu, Qiang. The Communicative Approach to English Teaching and Testing [M]. Shanghai: Shanghai Foreign Language Education Press. 2000 